\title{
A NEW BRACHIOPOD, RENSSELAERIA MAINENSIS, FROM THE DEVONIAN OF MAINE.
}

\author{
By Henry Shaler Williams, \\ Of Cornell University, Ithaca, New York.
}

In the discussion of the fauna of the Chapman sandstone of Presque Isle Brook, Edmunds Hill, and other localities in Chapman County, Maine, I referred to one of the most conspicuous and common fossils of the fauna under the name "Rensselaeria (Beachia) n. s., cf. B. suessana," and there made the following remark:

The abundant and great development of the Rensselaeria is a notable feature of the fauna. The specimens are provisionally referred to $R$. suessana, which they most nearly approach among the American forms in generic characters. Comparisons with the figures of Terebratula trigiceps, referred by Keyser and others to Rensselaeria, as well as study of the faunal associates, leads me to the opinion that the Maine specimens may be identical with the European forms. The name Rensselaeria mainensis is provisionally proposed for the form."

As the material was further studied and illustrations of it were being prepared, the expectation was strong that the species would prove to be only an extreme variety, due to shell thickening of a species such as $\dot{R}$. (B.) suessana or $R$. (B.) ovalis. Comparison has, however, brought to light no described species to which it may be referred, and its specific characters I now believe will stand. The shell is thick and massive and in its general form it resembles Rensselaeria (Beachia) suessana. It is much developed at the beak of the pedicle valve; the shell substance of the umbonal region of the pedicle valve is greatly thickened, and the cardinal margin is raised and produced into a distinct flattened pseudo-area in the plane of the edge of the valves. If it were not for the fact that the genus Rensselaeria, occasionally, has a distinct flattening of the area which is clearly represented in some figured specimens and is shown on plates of the several species, a new genus might be erected for this character. In the revised description of Rensselaeria and of the subgenus Beachia, Hall and Clarke distinctly refer to this feature. In the description

a Contribution to the Geology of Maine, Williams and Gregory, U. S. Geol. Survey Bull. No. 65,1900 , p. 80 . 
of the former genus we find "beneath and on each side of the beak is a concave, sharply defined space, but no proper cardinal area." In the description of Beachia it is stated that: "The cardinal margin beneath the beak is flattened into a well-defined pseudo-area. ${ }^{a}$ In the specimens before us there is a distinct flattened cardinal area the presence of which is the natural consequence of the great thickening and elevation of the beak portion of that valve. To the writer this difference is not of more than specific rank; the younger forms present only a trace of the areal flattening. In the following description of the species this character is therefore regarded as one of the specific marks of the Maine specimens consequent upon the extreme thickening of the shell.

The accompanying figures represent the molds of the interior of a pedicle and brachial valve of full size, as they appear in the rocks of Chapman Township, Aroostook County, Maine.

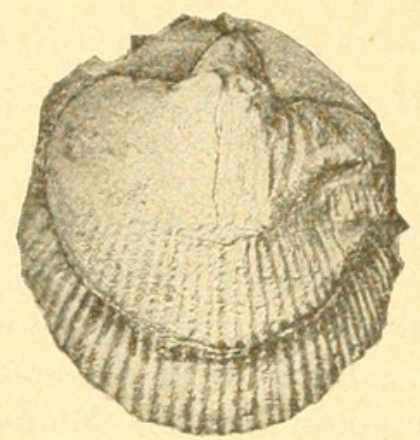

Fig. 1.-RENSSElaEria MAINENSIS, MOLD OF INTERIOR OF PEDICLE VALVE. NAT. SIZE.

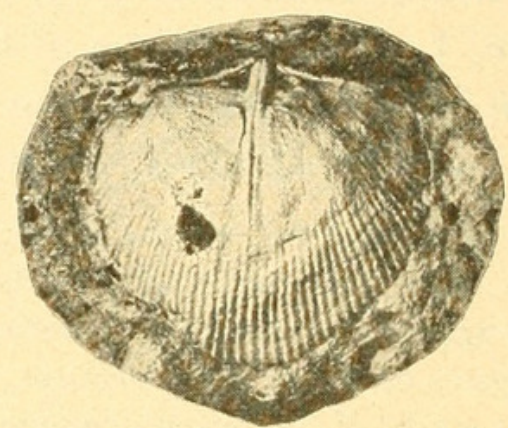

Fig. 2,-Rensselaeria Mainensis, MOLD OF INTERIOR BRACHIAL VALVE. NAT. SIZE.

RENSSELAERIA MAINENSIS, new species.

A medium-sized rensselaeroid form of the shorter ovate type approaching $R$. suessana in contour, but greatly developed at the umbonal end of the pedicle valve. The beak of the pedicle valve is lengthened and somewhat pointed, as in R. mutabilis; it is elevated above the beak of the brachial valve by a high pseudo-cardinal area, in which is a triangular delthyrium, open in all specimens preserved. The edges of the delthyrium are bordered by a narrow flattened margin which may be the support of the original deltidial plate or plates, which are wanting in all specimens preserved. These flattened margins of the delthyrium meet at the apex of the delthyriun below the circular foramen, which is nearly terminal.

The greatest width of the shell is at about one-third distance from the beaks. The average size of mature shells is about one inch in length and a little less in greatest width.

The pedicle valve is ventricose and in some of the larger shells near the beak is half an inch in depth. The brachial valve is convex and evenly rounded, about one-half as deep as the opposite valve; neither valve shows any median depression or furrow. The beak of the pedi- 
cle valve extends upward with only slight inward curvature directly above the cardinal area, which lies nearly in the plane of the margin of the shells, the tip of the beak slightly overarching the pseudo-area. The angle formed by the sides of the beak is from $120^{\circ}$ to $140^{\circ}$.

The surface ornamentation is made up of strong linear striæ, of which 45 to 75 can be counted, consisting of rounded thread-like ridges separated by rounded grooves, giving the surface a striate appearance somewhat coarser than that of normal $R$. ovoides.

The musculature is strong in well-preserved specimens and corresponds very closely to that of Beachia suessana for both the pedicle and brachial valves. The crural bases are two widely separated, strong, round bars in the molds leaving two well-defined holes each side of the base of the cardinal process. No evidence of the shape of the brachial supports is present. The shell structure appears to be fibrous; no punctre have been discovered. The visceral foramen is indicated.

The molds of the interior differ greatly, according to the age and strengthening of the shell, especially the pedicle valve. In the younger shells the dental lamellæ are thin and separate two lateral cavities from the central muscular cavity. The lateral carities reach nearly to the hinge margin. As the umbonal cavity of the shell becomes filled, by thickening of the shell substance, the central muscular cavity between the hinge plates is represented in the mold by a rounded ridge bounded by the dental lamellæ, the lateral cavities being completely filled by shell deposit. This rounded ridge, extending beakward from the main mass of the internal filling of the shell in the molds, increases in width with the elevating of the pseudo-area. In extreme examples the shell deposit is fully one-fourth inch in thickness, thus giving to the interior markings of the shells great difference of form, according to the age of the shell.

Type. - The two specimens figured are designated as cotypes of the species. They are now in the collection of the U. S. Geological Survey, with the other material on which the description is based, and will be transferred to the U. S. National Museum.

The species is abundant in the shales and sandstones of the Chapman formation of Presque Isle Brook and Edmunds Hill in Chapman Township, Aroostook County, Maine. 


\section{$2 \mathrm{BHL}$ Biodiversity Heritage Library}

Williams, Henry Shaler. 1907. "A new brachiopod, Rensselaeria mainensis, from the Devonian of Maine." Proceedings of the United States National Museum 32(1527), 267-269. https://doi.org/10.5479/si.00963801.32-1527.267.

View This Item Online: https://www.biodiversitylibrary.org/item/53434

DOI: https://doi.org/10.5479/si.00963801.32-1527.267

Permalink: https://www.biodiversitylibrary.org/partpdf/51875

\section{Holding Institution}

Smithsonian Libraries

\section{Sponsored by}

Smithsonian

\section{Copyright \& Reuse}

Copyright Status: Public domain. The BHL considers that this work is no longer under copyright protection.

This document was created from content at the Biodiversity Heritage Library, the world's largest open access digital library for biodiversity literature and archives. Visit BHL at https://www.biodiversitylibrary.org. 